\title{
Effect of Temperature Humidity Index on Semen Characteristics of Buffalo Bull
}

\author{
Mridula Sharma $^{1 *}$, Anoop Singh ${ }^{1}$, Bhat Yaqoob ${ }^{1}$, Mayank Maithani ${ }^{1}$, Shriya Rawat ${ }^{2}$ and \\ Nishant Sharma ${ }^{3}$ \\ ${ }^{1}$ Department of Veterinary Gynaecology and Obstetrics, College of Veterinary and Animal \\ Sciences, G.B Pant University of Agriculture and Technology, Pantnagar-263145, \\ Uttarakhand, India \\ ${ }^{2}$ SVPUA\&T, Meerut, India \\ ${ }^{3}$ Veterinary Officer at Animal Husbandry Department, Uttarakhand, India \\ *Corresponding author
}

\section{A B S T R A C T}

\begin{tabular}{|l|}
\hline Key w or d s \\
$\begin{array}{l}\text { Season, Temperature } \\
\text { humidity index, Semen } \\
\text { quality parameters, } \\
\text { Buffalo bull }\end{array}$ \\
\hline Article Info \\
\hline $\begin{array}{l}\text { Accepted: } \\
\text { 26 July 2018 } \\
\text { Available Online: } \\
\text { 10 August 2018 }\end{array}$ \\
\hline
\end{tabular}

The present study was undertaken to investigate the effect of temperature humidity index (THI) on various seminal attributes in buffalo bulls. Forty one ejaculates (41) from two buffalo bulls of 4 to 6 years weighing 500 to $750 \mathrm{kgs}$ reared at semen production centre, Department of Veterinary Gynaecology and Obstetrics, Pantnagar India, were used. Semen was collected twice a week through AV method for 6 months. The temperature and relative humidity of respective days was taken from meteorological department located nearby. Three groups were formed on the basis of THI i.e. Group I (64 to 72, n=10), Group II ( 72 to $78, n=13)$ and group III ( 78 to $84, n=18)$. Data was analyzed by least square of mean analysis to assess the effect of THI on various semen quality parameters. THI had no significant effect on ejaculate volume and $\mathrm{pH}$ but it had a significant $(\mathrm{P}<0.05)$ effect on mass motility and progressive motility. The results of this study indicated that the mass motility and progressive motility of the semen is found highest at the THI value of 72-78 and lowest at the THI value of 78-84.

\section{Introduction}

Water buffalo breeding is an activity of great economical potential and the global buffalo herd has grown in an annual rate of over $2 \%$ in the last two decades, mainly in developing countries (Sethi, 2013). The buffalo is a homoeothermic animal, but when submitted to elevated temperatures and relative humidity may undergo heat stress (Moraes Júnior et al., 2010). However, around 85\% of domestic buffaloes are raised in the intertropical zone, which predisposes these animals to a situation of permanent thermal challenge (Garcia, 2013). Since heat stress is a challenge for reaching superior animal husbandry indexes, different technologies in environmental and animal monitoring have been employed in the called "precision farming". Their use allows for the evaluation of environmental effects on animal production and can aid in decision making in herd management (Hoffmann et al., 
2013). Animal climatology as a subject of systemic study in recent years has gained recognition and the results obtained emphasize the importance of further improved and intensive study of the subject in relation to animal productivity. Studies carried out under controlled conditions have revealed that both the magnitude and duration of stress induced by the adverse environmental condition, particularly temperature and humidity factor influences the animal's physiological reactions and production, in the experimental location. In the tropical climate heat stress is largely responsible for the low animal productivity. The identification of the environmental factors which may affect sperm production and the quality of the semen has a major importance in improvement of bull fertility. Seasonal effects on semen quality have been observed in several species including rams (Mickelsen et al., 1981), Boer and Angora goats and rams (Greyling and Grobbelaar, 1983), and Sahiwal and Brahamn crossbred bulls (Wildeus et al., 1984). However, contradictory results were observed between different investigations concerning the effects of different seasons on semen quantity and quality. Most previous investigations indicated slightly higher semen quantity and quality during hot and humid periods during which mean temperature and humidity are high than during the colder months (Wierzbowski et al., 1980). Hence in this present study temperature and humidity factor of environment were studied to find its effect on semen quality of cross bred bulls.

Sperm quality is influenced by environmental factors such as temperature, humidity, atmospheric pressure, and day length. Elevated testicular temperatures, either by exposure to high ambient temperatures or high body temperature, have been identified as causing a disruption in spermatogenesis, producing sperm abnormalities with a consequent decrease in semen quality, which eventually may result in a decrease in embryo quality or in the failure of the embryo to signal maternal recognition of pregnancy (Bhuiyan and Shamsuddin, 1998; Mathevon et al., 1998). Maintaining testicular temperature below body temperature is essential for production of fertile spermatozoa in species with extra-abdominal testes (Waites, 1970). The optimal environmental temperature for sperm production is estimated to range between 15 and $18^{\circ} \mathrm{C}$ for the entire spermatogenesis period, i.e. for $65-70$ days before collection (Parkinson, 1987). Not only temperature on day of collection, but also during epididymal maturation or spermatogenesis up to about 70 days before collection seems to affect semen production (Stephan et al., 1971; Meyerhoeffer et al., 1985; Dorst, 1991; Kramer, 2000). However, notable differences between individual bulls were reported, suggesting differences in particular heat tolerance. The knowledge of trend of seasonal influence on semen characteristics would help to know the requirement of bulls to meet the demand of frozen semen and to provide any suitable additional managerial requirements time to time. Hence, the present study was undertaken to investigate the effect of seasons in reference to ambient temperature and relative humidity on semen characteristics of the cattle bull.

\section{Materials and Methods}

The present experiment was conducted on 41 ejaculates from 2 buffalo bulls aged 5 to 6 years weighing 500 to $750 \mathrm{~kg}$ body weight) maintained at Semen Production Centre, Department of Veterinary Gynaecology and Obstetrics, Pantnagar, India. The bulls were healthy, free from diseases, sexually mature, of good libido and clinically normal. Semen was collected in the morning twice a week during different months of year i.e. April to October 2015. After collection the volume of semen was measured and color and consistency were assessed. The consistency 
was graded (4-0 scale) as thick creamy, thin creamy, milky, cloudy and clear white. The $\mathrm{pH}$ was measured by Whatmann's $\mathrm{pH}$ indicator paper. Then the semen tube was placed in a water bath at 37c. Motility of spermatozoa was estimated within 10-15 min from the time of semen collection. Mass motility was determined by placing a small drop of fresh undiluted semen on a glass slide warmed to $34 \mathrm{c}$ and examined under the low power microscope. A score of 0-5 was given according to the intensity of swirling patterns. Progressive or individual motility was examined by placing one to two drops of diluted semen on a glass slide covered with cover slip, using high power microscope. The percentage of individual spermatozoa displaying progressive motility across the field was estimated and recorded. The temperature and relative humidity of respective days were taken from metrological department located nearby. THI was calculated and three groups were prepared on the basis THI range ie THI $<72$ (Group I, $\mathrm{n}=10$ ), 72-78 (Group II, $\mathrm{n}=13$ ) and 78-84 (Group III, $\mathrm{n}=18$ ). The recorded data were subjected to statistical analysis using Least squares means model and ANOVA using LSML-91 software package, Walter Harvey.

\section{Results and Discussion}

Figure 1 indicates the effect of THI on volume of semen collected from Buffalo bull. The appearance of the ejaculate varied between light milky and creamy. The analyses revealed that there was no significant difference in semen volume. Though the volume did not change significantly, but highest semen volume was observed in group I. Lowest volume of semen was estimated in group III.

The $\mathrm{pH}$ of semen observed during the experimental period was in normal range as 6.4-6.8 (Fig. 2). There was no significant change in $\mathrm{pH}$ of semen with increase in THI value. There was no change in $\mathrm{pH}$ of semen collected with the change in THI. The $\mathrm{pH}$ remained constant through the experiment with a mean value of.

The mass motility of the spermatozoa was between rapid (very good) and moderate (good). There was significantly $(\mathrm{P}<0.05)$ more mass motility in group II compared to group III (Fig. 3). The progressive motility was semen collected was between $70-85 \%$. Significantly $(\mathrm{P}<0.05)$ higher progressive motility was observed in group II compared to the group III (Fig. 4).

Although spermatogenesis is a continuous process in male once it has reached reproductive maturity, the semen of animals exhibits a distinct climatic pattern with respect to its quality and fertilizing efficiency, the most prominent factor being the temperature and humidity which in combination if more than the normal can lead to the deleterious effects on semen parameters. Although the above experiment provides information of the unfavorable effect of high temperature and humidity on the buffalo bulls reproductive performance, there is little information available from data collected under commercial AI conditions. Under field conditions, ambient temperature and relative humidity vary from day to day and ameliorate during the night. As a result, the response of the rabbits could be different from those observed under experimental conditions using climatic chambers. In rabbits It has been demonstrated that body temperature is at least temporarily increased when the environmental temperature exceeds 28 8C (Amici et al., 1995). Environmental conditions implicating heat stress as a causative factor in reduced reproductive performance of rabbits can begin to occur when the THI is $\mathrm{z} 27.88 \mathrm{C}$, and a severe heat stress may be found when the THIs up to $28.98 \mathrm{C}$ are reached (Marai et al., 2002). 
Fig.1 Effect of THI on volume of buffalo bull semen

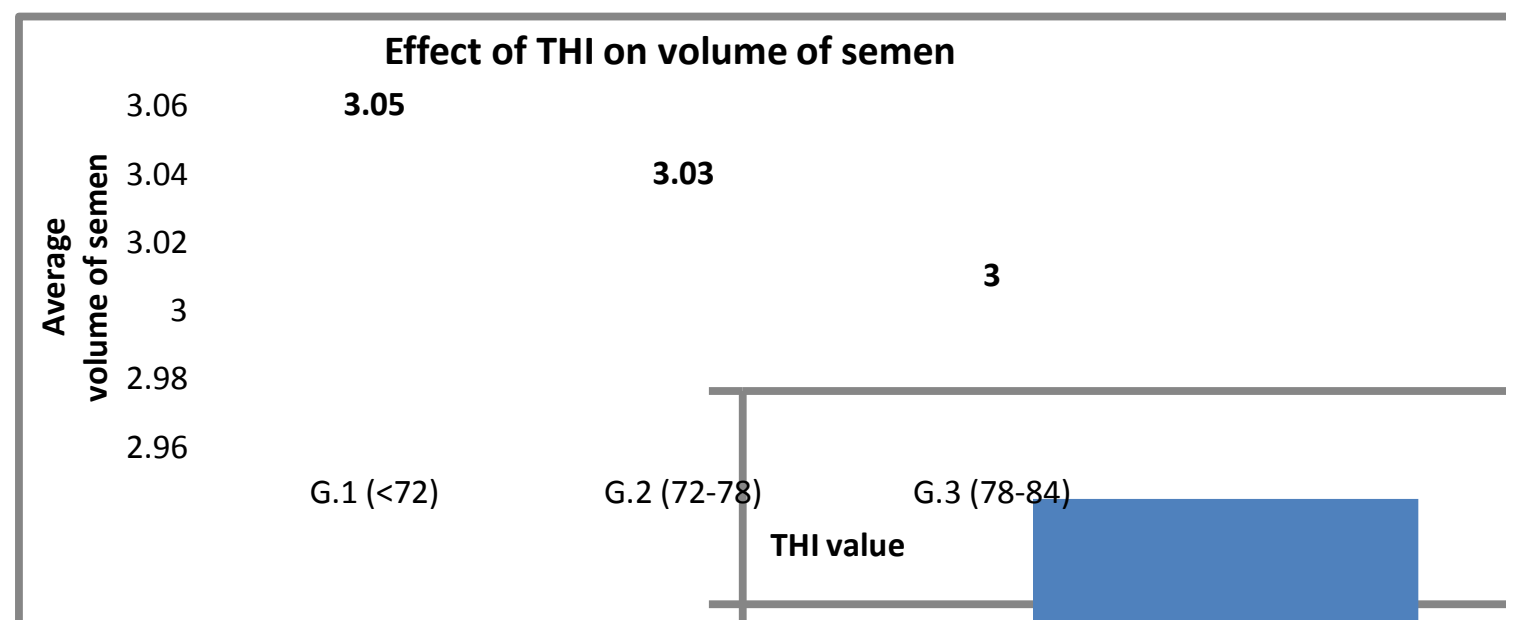

Fig.2 Effect of THI on pH of buffalo bull semen

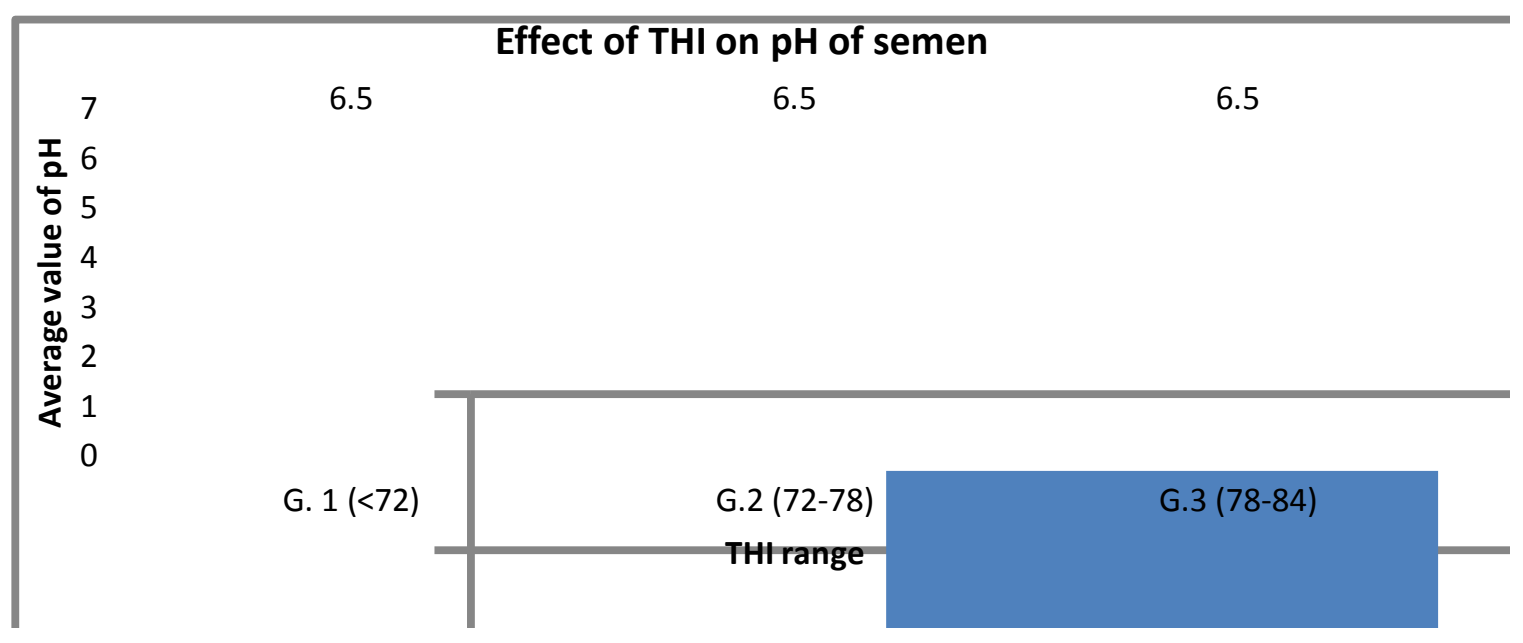

Fig.3 Effect of THI on mass motility of buffalo bull semen

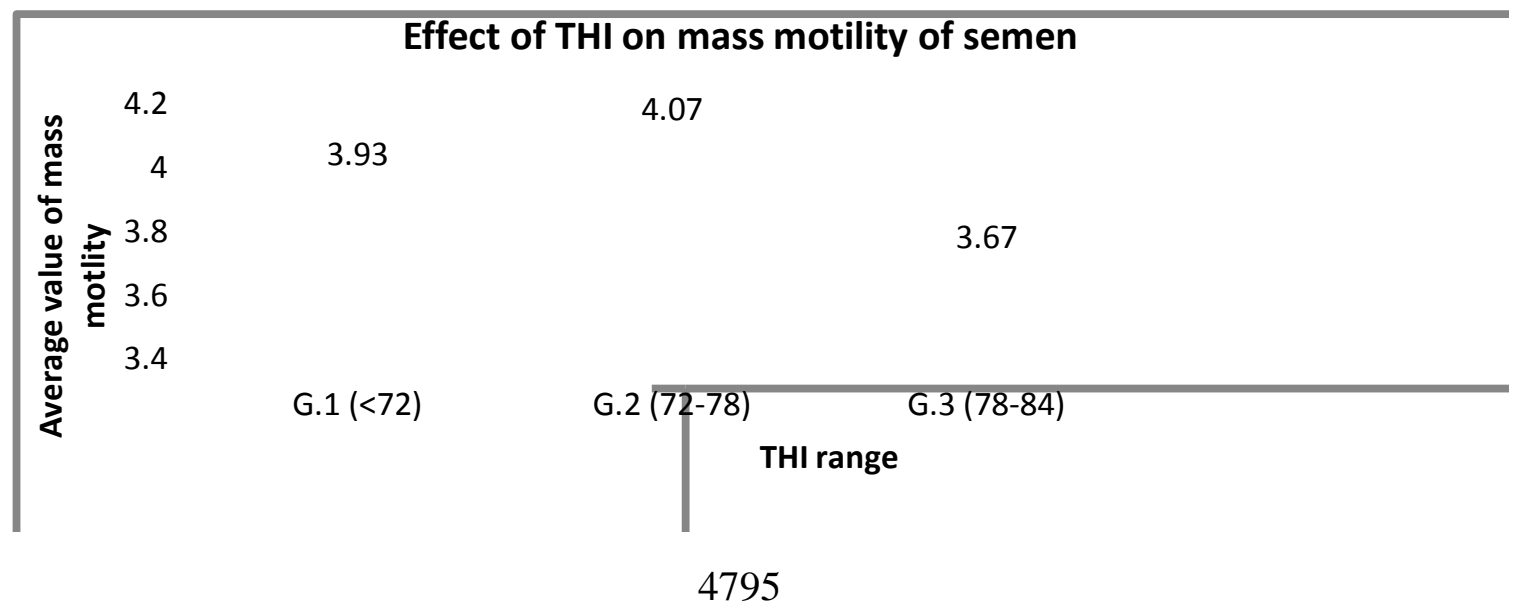


Fig.4 Effect of THI on Progressive motility of buffalo bull semen

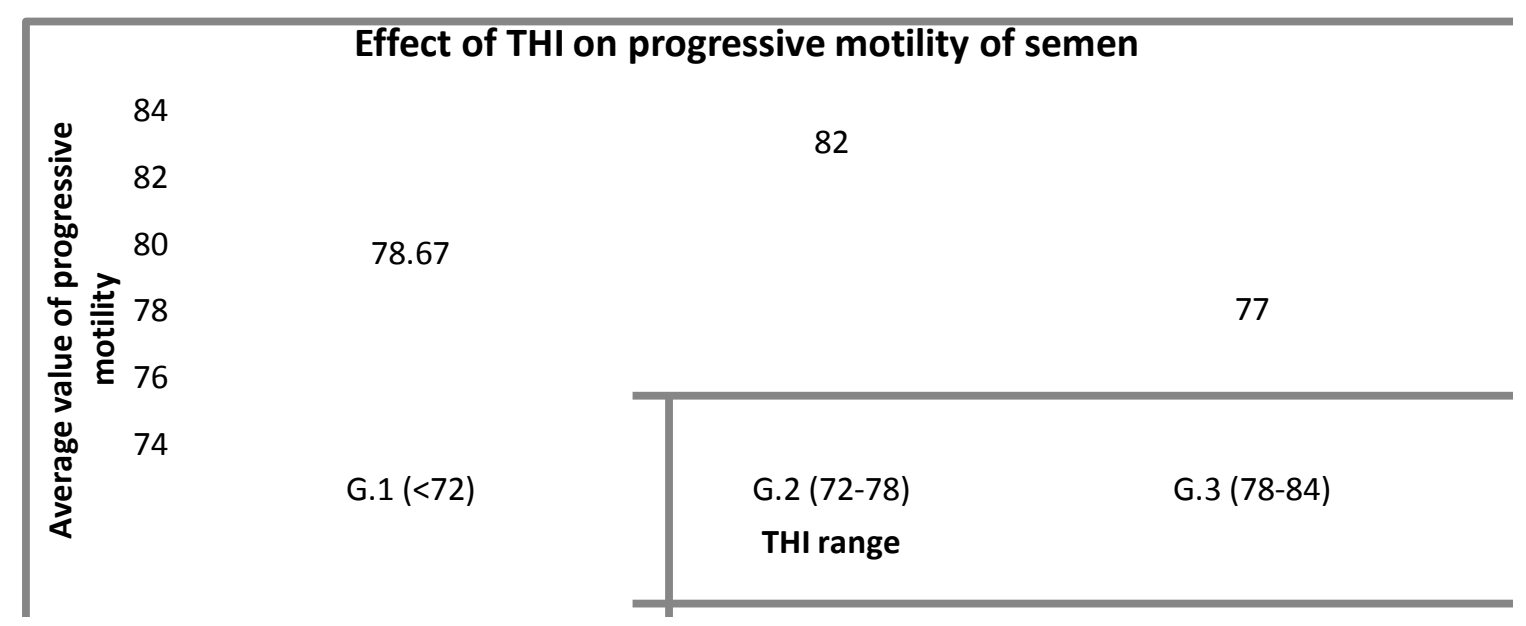

Our results indicate that volume and $\mathrm{pH}$ ejaculate parameters are not significantly influenced by THI but influence significantly the mass and the progressive motility of ejaculate. This could be because of the reason that spermatogenesis process is highly temperature sensitive and needs the proper temperature (appox $2 \mathrm{c}$ lower than the body temperature) to go on smoothly. The moderate and severe heat stress cause the increase in the testicular temperature which does not allow the proper maturation of sperms and leads to the production of abnormal and dead sperms and ultimately affecting the mass and progressive motility of ejaculate motility.

In our present study there was no significant difference in semen volume Our results are in agreement with the results obtained by Oloufa et al., (1959) in Egyptian buffalo bulls; Tomar et al., (1966) in Murrah bulls; Manik and Mudgal (1984) in Murrah buffalo bulls and Koonjaenak et al., (2007) in Swamp buffalo which reveal that season had no significant effect on volume of the ejaculate of buffalo bulls. In another study carried by Bhakat et al., (2015) on murrah bulls, they found no significant seasonal difference in ejaculate volume.
The $\mathrm{pH}$ parameter of ejaculate didn't change significantly with the increase in THI value. The $\mathrm{pH}$ remained constant through the experiment with a mean value of $6.50 \pm 0.33$. Our findings are in agreement with the findings obtained by Koonjaenak et al., (2007) in swamp buffalo who reported no significant seasonal variation in $\mathrm{pH}$. Mandal et al., (2000) also observed similar results in Murrah buffalo bulls. On the contrary, Bhakat et al., (2015) found Significant $(\mathrm{P}<0.05)$ seasonal difference in $\mathrm{pH}$ of ejaculate in murrah bulls which may be due to due to seasonal fodder changes and due to silage feeding. Our studies indicate significant effect of THI on mass motility of semen collected. The mass motility of the spermatozoa was between rapid (very good) and moderate (good). Significant increase in mass motility was seen as the THI value increased from 72 to 78 and then decreased significantly as the THI increased further from 78 to 84 . Mass motility of the semen was found highest at the THI value of $72-78(4.07 \pm 0.18)$ and lowest at the THI value of 78-84 (3.67 \pm 0.34$)$. Zafar $e t$ al., 1988 obtained no significant seasonal variation in mass activity in a study conducted on Nili-ravi bulls which are in contrary to our findings. Our results are in agreement with the finding that the highest mass activity is 
present during winter season as reported in Murrah buffalo bulls (Manik and Mudgal, 1984; Mandal et al., 2000); Mehsana (Prajapati, 1995) and Surti buffalo bulls. During winter season THI level is in normal range (Bhosrekar et al., 1992), however in Murrah bulls, Bhosrekar, 1980 and Dhami et al., 1998 it was highest during rainy season, during which THI level remains high.

In our study the highest progressive motility $(82.00 \pm 2.92)$ was observed at the THI value of 72-78. The lowest progressive motility (77.00 \pm 4.17$)$ being recorded at THI value of 78-84. The results of the present study showed that there was a significant decrease in progressive motility in group 3 with respect to group 2 with the increase in the mean value of THI from 75.95 to 80.54 . Our results are in agreement with the findings obtained by of Tuli and Singh (1983) in Murrah buffalo bulls and Bhosrekar et al., 1992 in Surti buffalo bulls and Ravimurugan et al., (2003) in Murrah buffalo bulls who found the Significant $(\mathrm{P}<0.01)$ seasonal difference in percent initial motility. The initial motility was found to be maximum during winter (65.95 vs. 56.18 and $59.64 \%$ ) during which THI value remains in normal range and varied significantly $(\mathrm{P}<0.05)$ in summer and rainy season. On the contrary, Oloufa et al., (1959) in Egyptian buffalo bulls; Gupta et al., (1978) in Surti buffalo; Zafar et al., (1988) in Niliravi buffalo bulls; Bhosrekar et al., (1991) in Murrah buffalo bulls; Prajapati (1995) in Mehsana; Mandal et al., (2000) in Murrah buffalo bulls and Koonjaenak et al., (2007) in Swamp buffalo did not obtain any significant seasonal variation in IM.

Thus, it may be concluded that the hot-dry or summer season during which THI values are found to be towards higher side affect the various biophysical characteristics of semen in buffalo bulls. Progressive motility and mass motility gets decreased significantly at high THI. THI values in normal range (winter) was the most favorable season for good quality semen production.

In general it is suggested that during summer, breeding bulls should be kept cool and comfortable by splashing water at least 3-4 times a day, protected from direct wind blasts, housed in a place with comfortable microenvironment with least humidity, fed during cool hours and have a free access to cool drinking water.

\section{Acknowledgement}

Authors are thankful to the Dean, College of Veterinary and Animal Sciences and Joint Director, IDF, DES GBPUA \& T, Pantnagar, for facilities and financial assistance extended during the course of study

\section{References}

Amici, A., Finzi, A., Mastroiacono, P., Nardini, M., Tomassi, G., 1995. Functional and metabolic changes in rabbits undergoing continuous heat stress for 24 days. Anim. Sci. 61, $399-$ 405.

Bhakat, M., T.K. Mohanty1, A.K. Gupta1, S. Prasad2, A.K. Chakravarty1 and H.M. Khan. 2015. Effect of Season on Semen Quality Parameters in Murrah Buffalo Bulls. Buffalo Bulletin (March 2015) Vol.34 No.1

Bhosrekar, M.R. 1980. Studies on buffalo semen. Seasonal variation in seminal characteristics. Indian Vet. J., 57: 806810

Bhosrekar, M.R., S. Mokashi, J.R. Purohit, S.B. Gokhale and B.R. Mangurkar. 1991. Studies on the effect of deep freezing and seasons on the leakage of aspertate amino transferase into extracellular medium and sperm 
morphology of Murrah buffalo bulls. Anim. Reprod. Sci., 26: 219-226.

Dhami, A.J., M. Greesh and K.L. Sahni. 1998. Seasonal influences on the quality and freezability of semen of Friesian and Murrah buffalo bulls. Indian J. Anim. Reprod., 19(1): 55-58.

Dorst, J., 1991. Morphologie des Geschlechtssystems. In: Busch, W., Lohle, K., Peter, W. (Eds.), Kunstliche Besamung bei Nutztieren. Gustav Fischer Jena, Stuttgart, pp. 169-208

GARCIA, A.R. Conforto térmico na reprodução de bubalinos criados em condições tropicais. Rev. Bras. Rep. Anim., v.37, p.121-130, 2013.

GARCIA, A.R., MATOS, L.B., LOURENÇO JÚNIOR, J.B. et al., Variáveis fisiológicas de búfalas leiteiras criadas sob sombreamento em sistemas silvipastoris. Pesqui. Agropecu. Bras., v.46, p.1409-1414, 2011.

Greyling, J.P.C. and Grobbelaar, J.A.N. (1983). Seasonal variation in semen quality of Boer and Angora goat and rams using different collection techniques. S. Afr. J. Anim. Sci. 13: 250.

Gupta, H.C., M.C.S. Naik and R.K. Srivastava. 1978. Effect of age and season on certain characteristics of Surti buffalo bulls. Indian J. Dairy Sci., 31(3): 245-252.

Hoffmann, G., Schmidt, M., Ammon, C. et al., Monitoring the body temperature of cows and calves using video recordings from an infrared thermography camera. Vet. Res. Commun., v.37, p.91-99, 2013

Koonjaenak, S., V. Chanatinart, S. Aiumlamai, T. Pinyopumimintr and $\mathrm{H}$. Rodriguez-Martinez. 2007a. Seasonal variation in semen quality of swamp buffalo bulls (Bubalus bubalis) in Thailand. Asian J. Androl., 9(1): 92101.

Kramer, T., 2000. Untersuchungen uber den Einfluss erh ohter Außentemperaturen auf verschiedene Ejakulatmerkmale sowie biochemische und hormonelle Parameter bei in der Klimakammer und unter subtropischen Klimaverhaltnissen " gehaltenen Bullen. Ph.D. Thesis, Freie Universitat, Berlin.

Mandal, D.K., P.K. Nagpaul and A.K. Gupta. 2000. Seasonal variation in seminal attributes and sexual behaviour of Murrah buffalo bulls. Indian J. Dairy Sci., 53: 278-283.

Manik, R.S. and V.D. Mudgal. 1984. Monthly and seasonal variation in physicochemical and biochemical attributes of buffalo semen. World Rev. Anim. Prod., 4: 45-50.

Marai, I.F.M., Habeed, A.A.M., Gad, A.E., 2002. RabbitsT productive, reproductive and physiological performance traits as affected by heat stress: a review. Livest. Prod. Sci. 78, $71-90$.

Mathevon, M., Buhr, M.M., Dekkers, J.C., 1998. Environmental, management, and genetic factors affecting semen production in Holstein bulls. J. Dairy Sci. 81 (12), 3321-3330.

Meyerhoeffer, D.C., Wettemann, R.P., Coleman, S.W., Wells, M.E., 1985. Reproductive criteria of beef bulls during and after exposure to increased ambient temperature. J. Anim Sci. 60 (2), 352-357.

Mickelsen, W.D., Paisley, L.G. and Dahmen, J.J. (1981). The effect of season on the scrotal circumference and sperm motility and morphology in rams. Theriogenology 16:45.

Moraes Júnior, R.J., Garcia, A.R., Santos, N.F.A. et al., Conforto ambiental de bezerros bubalinos (Bubalus bubalis Linnaeus, 1758) em sistemas silvipastoris na Amazônia Oriental. Acta Amaz., v.40, p.629-640, 2010.

Oloufa, M.M., A.A. Sayed and A.L. Bareldin. 1959. Seasonal variation in reaction 
time of Egyptian buffalo- bulls and physiochemical characteristics of their semen. Indian J. Dairy Sci., 12: 10-17.

Parkinson, T.J., 1987. Seasonal variations in semen quality of bulls: correlations with environmental temperature. Vet. Rec. 120 (20), 479-482

Prajapati, K.B. 1995. The effect of exercise and feeding bypass protein on sexual behavior and seminal attribute in Mehsana buffalo. Ph.D. Thesis, NDRI Deemed University, Karnal, India.

Ravimurgan, T., K.S. Raman and P. Thangaraju. 2003. Seasonal infl uences on the semen production traits of Murrah buffalo bulls. Indian Buffalo J., 1(2): 85-87. Anim. Sci., 62(5): 443-447.

Sethi, R.K. Breeding strategies for genetic improvement in buffaloes. Buffalo. B., v.32 (Special Issue 1), Pp. 219-226, 2013.

Somparn, P., Gibb, M.J., Markvichitr, K. et al., Analysis of climatic risk for cattle and buffalo production in northeast Thailand. Int. J. Biometeorol., v.49, p.59-64, 2004.

Stephan, E., Lorrmann, W., Dycka, J., 1971. Zur Problematik der Klimaempfindlichkeit bei Haustieren (III). Auswirkungen experimenteller Warmebelastungen auf Bullen -1 . Mitteilung: Einige meßbare
Eigenschaften des Ejakulates. Zuchthygiene 1, 19-38.

Tomar, N.S., B.S. Mishra and C.B. Johari. 1966. Seasonal variations in reaction time and semen production, and prediction of some semen attributes on initial motility of spermatozoa in Hariana and Murrah bulls. Indian J. Dairy Sci., 19: 87-93.

Tuli, R.K. and M. Singh. 1983. Seasonal variation in freezability of buffalo semen. Theriogenology, 20: 321-324.

Waites, G.M.H., 1970. Temperature regulation and the testis. In: Johnson, A.D., Gomes, W.R., Vandemark, N.L. (Eds.), The Testis, vol. 1. Academic Press, London, pp. 241-279

Wierzbowski, S., Tahir, M.N., Hamblin, F.B. and Shafi, M. (1980). Service ability and semen production of buffaloes. World Anim. Rev. 33: 26.

Wildeus, S., Holroyd, R.G. and Entwistle, K.W. (1984). Patterns of puberal development in Sahiwal and Brahman cross bulls in Tropical Australia. 1. Growth and semen characteristics. Theriogenology 22: 361

Zafar, A.H., N. Ahmed and S.K. Shah. 1988. Effect of seasonal variation on semen production of Nili-Ravi buffalo bulls. Buffalo J., 4(1): 61-68.

\section{How to cite this article:}

Mridula Sharma, Anoop Singh, Bhat Yaqoob, Mayank Maithani, Shriya Rawat and Nishant Sharma. 2018. Effect of Temperature Humidity Index on Semen Characteristics of Buffalo Bull. Int.J.Curr.Microbiol.App.Sci. 7(08): 4792-4799. doi: https://doi.org/10.20546/ijcmas.2018.708.504 